\title{
NEW REGULATION OF NON-CONTENTIOUS PROCEDURES \\ WITH AN EMPHASIS ON THE PROCEDURE OF PLACING ADULTY UNDER CUSTODY IN SLOVENIA
}

\author{
Tjaša IVANC \\ Associate Law Professor, Faculty of Law, University of Maribor, Slovenia \\ E-mail: tjasa.ivanc@um.si
}

\begin{abstract}
Due to the need to harmonize procedural rules of non-contentious procedures with the new conceptual solutions of the Family Code in the area of family relationships, the adoption of the new NonContentious Civil Procedure Act in Slovenia was necessary. The analysis of comparative legal examples shows that family matters need to be tackled as fully and uniformly as possible, which the non-contentious rules, with a more flexible and less formal nature, certainly enable. The article discusses the necessary procedural adjustments of the fundamental principles and general provisions of the non-contentious procedure. Arguments are based on a general overview of the German and Austrian rules, which are most comparable to the Slovenian system. In both jurisdictions, family matters are decided in a non-contentious proceeding. The author further deals with the new regulation for placing an adult under custody. Due to a mental development disorder or mental health problems, or other causes affecting the ability to make a judgement, such adults are unable to take care of their rights and benefits without harming themselves. The legislature followed comparative examples and eliminated the double-track procedures for deprivation of legal capacity. The new regulation allows for the diversity of the extent of the inability to make independent and reasonable decisions. However, the system of custody, which is voluntary in Slovenia, remains an unresolved problem. The institution of a custodian should be systematically regulated in a particular Act that would ensure the professionalism of persons and regulate compensation for the custodial services provided.
\end{abstract}

Keywords: non-contentious civil procedure, family matter, the concept of non-contentious procedure, procedure of placing adults under custody in Slovenia 


\section{Introduction}

Due to their nature, non-contentious procedures are of special importance, as they regulate some essential segments of citizens' lives. Such decisions may interfere with fundamental human rights regarding personal and family status, and inheritance and private property.

The new Non-Contentious Civil Procedure Act (NCCPA-1) has been planned in Slovenia for a long time, but the legislature's main work momentum was triggered primarily by the short deadline set for the urgent harmonization with the new Family Code (FC). (Kraljić, 2020).

Non-contentious procedures in Slovenia developed mainly under the influence of theoretical considerations in the legal literature and the views of case law, especially before higher courts. The old Non-Contentious Civil Procedure Act (NCCPA) has been in force without major changes since 1986. Innovations were introduced in individual sectoral substantive laws, but such partial regulation required systemic harmonization. Expansion of courts jurisdiction in the field of family, inheritance, property, housing law, land register, and commercial law created the need to verify the fundamental principles and general procedural provisions. Since the process of adopting a new noncontentious Act was subordinated to the reform of the FC (Kraljić, 2020), there is a concern as to whether the general section was sufficiently analysed in terms of property non-contentious procedures. Perhaps too much emphasis is placed on bringing these non-contentious procedures closer to contentious procedures, thus losing the added value allowed by non-contentious procedures.

Due to their common roots, the Austrian regulation is the most comparable to the Slovenian regulation of non-contentious procedures, followed by the German regulation, in which some advanced solutions have been inured. In Austria, after many years of preparations, a comprehensive reform of noncontentious procedures was carried out with the new, very detailed NonContentious Civil Procedure Act (Außerstreitgesetz - AußStrG). ${ }^{1}$ In Germany, an important reform of non-contentious procedures ${ }^{2}$ and family law was likewise introduced in 2008 by the Family and Non-Contentious Civil Procedure Act (Gesetz über das Verfahren in Familiensachen und in den Angelegenheiten der freiwilligen Gerichtsbarkeit - FamFG). ${ }^{3}$ Reforms in Austria and Germany have introduced changes to the general rules of noncontentious law. The objective was to eliminate obsolete and deficient provisions of non-contentious regulations. In Austria, the Non-Contentious Civil Procedure Act (Gesetz über das gerichtliche Verfahren in

1 Bundesgesetz über das gerichtliche Verfahren in Rechtsangelegenheiten außer Streitsachen (BGBl. I, No. 111/03, last amendment BGBl. I, No. 58/18).

${ }^{2}$ Gesetz zur Reform des Verfahrens in Familiensachen und in den Angelegenheiten der freiwilligen Gerichtsbarkeit (FGG-Reformgesetz - FGG-RG), BGBl. I S. 2586.

${ }^{3}$ BGBl. I S. 2586, 2587 of 17/12/2008 and last amendment Art. 7 G v. (BGB1. I S. 2780 of 20/07/2017). 
New regulation of non-contentious procedures with an emphasis on...

Rechtsangelegenheiten außer Streitsachen $)^{4}$ was effective as from 1854, and in Germany, the Non-Contentious Civil Procedure Act (Gesetz über die Angelegenheiten der freiwlligen Gerichtsbarkeit - FGG) ${ }^{5}$ was effective as from 1898 .

The Slovenian legislature has decided to transfer certain family matters, which were within the jurisdiction of civil courts, to the jurisdiction of noncontentious courts and thus enable comprehensive and uniform treatment, which the more flexible and less formal rules of non-contentious procedure allow. This makes it possible to deal with the entire family situation before the same court and according to the rules of the same type of court procedures.

In the past, many family matters in Slovenia were resolved by administrative bodies, e.g. allowing a child to wedlock, adoption procedures, which meant that decision-making in a particular family case was divided between the jurisdiction of contentious, non-contentious courts and administrative bodies. The Social Work Centres were responsible for deciding on the care and upbringing of children born out of wedlock, and for children born in wedlock whose parents could not agree on the exercise of parental rights, the court in contentious procedures are given juristiction for regulating relations in matrimonial disputes, relations with children in the event of divorce of marriage, custody, upbringing, contacts and maintenance. Non-contentious procedures were envisaged for the approval of parents agreements regarding care and upbringing, maintenance, and contacts (Rijavec in Ude, Galič, pp. 614615).

In theory, the judgment of the profession prevailed that the very nature and structure of administrative procedures do not provide the same protection in family matters as court procedures (Rijavec, 2020, p. 147). Therefore, the Slovenian FC transferred most of the decision-making authorizations to the courts, with only a few cases remaining under the jurisdiction of the Social Work Centres, e.g. mainly the authorizations regarding custody. However, with the adoption of NCCPA-1, there were further procedures in matrimonial matters such as divorce or annulment of marriage, procedures to establish and dispute paternity, and disputes concerning the custody, upbringing and maintenance of minors and disputes concerning children contacts with parents and other persons from the Slovenian Civil Procedure Act (CPA) transferred to NCCPA-1.

In this paper, the basic concepts of non-contentious procedures in the Germanic circle representaives of Austria, Germany will be presented. These are the most comparable to the Slovenian regulation, because in both legal orders family matters are resolved in non-contentious procedures. Basic concepts and

\footnotetext{
${ }^{4}$ RGBI. $1854 / 208$ of $09 / 08 / 1854$.

${ }^{5}$ RGBl. S. 369,771 of 20/05/1898.
} 
essential recognitions of the characteristics of non-contentious procedures in comparison with contentious procedures will be discussed.

Further, the new regulation of placing an adult under custody will be discussed. These are procedures that are becoming more and more common in Slovenia, but which had been inadequately regulated until the new regulation. The legislature has provided for a more appropriate mechanism.

\section{Individual emphases of non-contentious procedures in comparative legal systems}

\subsection{Definition of terms}

Different terms are used for the non-contentious procedure in individual system: in German - Außerstreitverfahren, Freiwillige Gerichtsbarkeit, in French - jurisdiction gracieuse, in English: non-contentious jurisdiction, in Portuguese - jurisdição voluntária. There is no single definition of the term. In comparative legal systems, the decision as to whether a particular civil case will be dealt with in contentious or non-contentious procedures is, as a rule, left to the legal policy decision of the legislature (Juhart, 1961, p. 99). The Constitutional Court of the Republic of Slovenia (Constitutional Court of the Republic of Slovenia, Decision UI-273/98 of 1 July 1999) emphasized that the legislature's decision on which matters would be settled in an individual procedure may not, however, be arbitrary and adopted the "without reasonable and substantial reason" criteria (Galič, 2017). In comparative systems, legislatures cited various reasons to assist in classifying cases into noncontentious procedures, such as the indisputability of the case, the nature of the case, which dictates interference in a particular area of social life, public interest, the lack of bilateral relations, the need for official authorizations, the need to anticipate the jurisdiction of the court to change legal relations, the nature of the state activities related to public records and issuing certificates (Misztal-Konecka (2018), pp. 572-573).

Examples from comparative systems in Austria, Germany, Slovenia, and Sweden show that the matter of non-contentious procedures can be codified in a special law or in the law on civil procedure as in Italy, France, and Finland, but it can be fragmented according to individual substantive laws without special general principles that would be generally applicable to non-contentious procedures as in countries with the Anglo-Saxon system.

In Germany, a number of civil cases can be resolved in non-contentious procedures, but these do not have common characteristics on the basis of which non-contentious cases could be distinguished from contentious cases (Rosenberg, Schwab, Gottwald, 2010, p. 63). There are many types of noncontentious procedures. They are most often used for those areas of civil law where the intervention of a judge is necessary in the interest of an individual 
New regulation of non-contentious procedures with an emphasis on...

who is not able to sufficiently protect his/her rights. In comparative legal systems, the resolution of more and more contentious cases have been transferred to non-contentious procedures. ${ }^{6}$

Both the Austrian AußStrG (in Article 1 paragraph 2) and the German FamFG (in Article 1) stipulate that the provisions of non-contentious procedure apply in all cases when this is provided by law, which means that a positivist approach is envisioned.

\subsection{Types of non-contentious procedures}

A wide range of specific non-contentious procedures is noticeable in comparative law.

In German legal theory, civil cases that dealt with in non-contentious procedures are classified into classic non-contentious cases, custody, registration procedures, inheritance; private disputes, border regulation, disputes between co-owners, emergency route and disputes among condominium owners; and public disputes, assessing the correctness and legality of decisions issued by judicial administration bodies (Habscheid, 1971, pp. 1-5). The most important non-contentious cases in Austria include: probate procedures (Article 20 of AußStrG et seq.), custody (Article 181 of AußStrG et seq.), relations between spouses (Article 220 of AußStrG et seq.), relations between parents and children, adoptions (Article 257 of AußStrG et seq.), detention of persons with mental health problems ${ }^{7}$ and a number of cases in the fields of housing, land registry and registration law. ${ }^{8}$

As to the way of initiating the procedure, non-contentious procedures can be classified into official and dispositive and mixed, which can be initiated either at the request of a party or a participant or ex officio.

Recent developments in German non-contentious law, governed at federal level until 2008 by the Federal Law on Non-contentious Procedure (Gesetz über die

\footnotetext{
${ }^{6}$ The Austrian legislature has determined the jurisdiction of a non-contentious court to decide independently in probate procedures, even in cases where a dispute of fact arises. The court is not obliged to suspend the probate procedure and refer the participants to the court, but only decides on this issue.

${ }^{7}$ This is regulated in the Detention Act, Unterbringungsgesetz, BGB1. No. 155/90 of 01/03/1990, last amendment BGBl. I, No. 131/17 of 02/08/2017.

${ }^{8}$ For comparison: in the Croatian literature, non-contentious procedures are classified into status (declaring a missing person dead, deprivation and return of legal capacity, deciding on parental rights and deprivation of parental rights, issuing permits for marriage, etc.) and procedures for resolving property relations (inheritance, division of co-ownership community, division of common property, land registry procedures, etc.). (Triva \& Dika, 2004, pp. 55-56).
} 
Angelegenheiten der freiwilligen Gerichtsbarkeit - FGG), ${ }^{9}$ was strongly marked in 2009 by the adoption of the comprehensive FamFG. This Act is now used as a basis for decision-making in non-contentious procedures, although it regulates mainly family matters. In Article 111, it exhaustively lists what belongs to family matters. The German legislature is not bothered by the fact that this Act also regulates classic disputes, such as matrimonial disputes, disputes arising from relationships concerning children, and disputes concerning the establishment or dispute of paternity or maternity. For these disputes, only the application of the rules of contentious procedures is regulated. Non-contentious procedures under this Act also include matters relating to adoptions, matters relating to the spouses housing and household equipment in the event of divorce or separation, matters relating to protection against violence, matters relating to pension insurance rights, maintenance matters, property relations between spouses, remaining family matters and matters of partner communities.

The Slovenian NCCPA-1 does not contain a definition for determining relations that are regulated in non-contentious procedures. A positivist or legal theory is used to distinguish between non-contentious and contentious procedures (Rijavec, 2020, p. 43), according to which personal status, family and property relations and other cases are dealt with in non-contentious procedures for which NCCPA-1 or other Acts stipulate that they are resolved in non-contentious procedures (Article 1 of NCCPA-1).

\subsection{Peculiarities of the regulation of the Germanic circle of non- contentious procedures}

From a comparative legal point of view, the rules of contentious procedures make it possible to fill in the processes of deficiencies and outdated regulations of non-contentious procedures. However, such nomotechnics can obscure the special nature of non-contentious procedures and bring them closer to contentious procedures. Compared to contentious procedures, the rules of noncontentious procedures are less strict, as they are less formal and more flexible than the rules of contentious procedures (Galič, 2000, p. 8). As a rule, this is not about classic dispute resolution, but a regulation of rights based on substantive provisions in the field of family law and personal and property relations.

The Slovenian NCCPA-1 contains a general reference regarding the subsidiary and reasonable application of the rules of contentious procedures and stipulates that the provisions of the Contentious Procedures Act (CPA) shall apply mutatis mutandis in non-contentious procedures, unless otherwise provided by law (Article 42 of NCCPA-1). NCCPA-1 also contains a number of specific

\footnotetext{
${ }^{9}$ RGBl. S. 189 of 17/05/1898.
} 
references to the application of CPA provisions, which can also be found in reverse cases where the application of CPA provisions is explicitly excluded (Keresteš in Rijavec, Galič, 2020, pp. 140-141).

The German and Austrian regulations do not contain a general reference to the rules of contentious procedures. In the German FamFG there is no general provision on the primary or reasonable application of the Civil Procedures Act (Zivilprozessordnung - ZPO) ${ }^{10}$ but directs on the appropriate application of the ZPO provisions in individual procedures and institutes in FamFG. In the Act, certain cases relating to maintenance issues, property relations between spouses and other family matters under Article 266 of FamFG and cases of partner communities under Article 269 paragraph 2 of the FamFG are marked as disputed family matters (Article 112 of FamFG entitled Familienstreitsachen). They are resolved on the basis of the ZPO provisions (Article 113 of FamFG entitled Anwendung von Vorschriften der Zivilprozessordnung). Furthermore, in certain cases, FamFG also explicitly excludes the application of the ZPO provisions (Article 113 paragraphs 3 and 4 of FamFG). In individual provisions, the Austrian AußStrG, even more often than the German FamFG, gives directions concerning the application of provisions of the Austrian Contentious Procedures Act (Zivilprozessordnung - ZPO).) ${ }^{11}$, e.g. at proxies and deadlines.

In theory, the chosen method, for example directing to ZPO in Article 113 of FamFG in family matters, does not allow a clear demarcation between the rules of contentious and non-contentious procedure, but causes procedural disorder (A. Maganić, 2015, p. 162).

The distinction between contentious and non-contentious procedures in FamFG can also be seen in the application of terminology from non-contentious law in cases where the provisions of the ZPO are applied to resolve a dispute. Thus, the term "proposal" is used instead of "claim" or "lawsuit", the term "submitter" is used instead of "plaintiff", the term "counterparty" is used instead of "defendant", and the term "participant" is used instead of "party".

Non-contentious procedures are indisputable by nature, but they also deal with disputed matters, which in most cases have been transferred to them from contentious jurisdiction. In comparative systems, legislatures have been led to transfer the effort to concentrate and accelerate the procedure (Rechberger, 2013, p. Xxxv). The Austrian regulation followed the principle of concentration and acceleration of procedures with the regulation in inheritance procedures and enabled the judge in probate procedures to decide on the disputed facts as a preliminary question in the same procedure and not to refer the parties to start contentious civil procedure to decide the disputed facts as the main matter (Article 161 of AußStrG). Thus, the judge carries out the evidentiary procedure

\footnotetext{
${ }^{10}$ RGBl. S. 83 of 30/01/1877.

${ }^{11}$ RGB1. No. $113 / 1895$ of $01 / 08 / 1895$.
} 
in non-contentious procedure and the suspension of the procedure until a final decision in the contentious procedure is not necessary. For the application of the new rules, the law provides for the strengthening of the principle of hearing the parties and other legal protection guarantees, as well as the rules of evidence intended to establish the disputed facts in the procedures. The procedures are held orally at the hearing. In the event that the probate value exceeds the statutory limit, the rules on substitution by a lawyer also apply. The restriction of the postulation right is envisaged for the case when the value of the probate assets exceeds EUR 5,000 and the parties must be substituted by a lawyer (Article 162 of AußStrG).

Under the German regulation pursuant to FamFG general provisions, the court may suspend the procedures when it has a valid reason to do so, in particular when the decision depends in whole or in part on the existence or non-existence of a legal relationship, which is the subject of another procedure pending or in jurisdiction of an administrative body (Article 21 of FamFG).

In Slovenia, the previous regulation according to which a non-contentious judge had limited jurisdiction to establish the disputed facts in relation to the previous question, was amended. Thus, under the old regulation the court had to suspend the procedures and refer the participant to contentious or administrative procedures if the solution of the existence of a right or legal relationship depended on the establishment of the disputed facts (Article 9 of NCCPA-1). Under the current regulation (Article 9 of NCCPA-1), following the example of the CPA, the court in non-contentious procedures is left to decide independently whether, in the event that the preliminary issue in the registry field has not yet been resolved, the preliminary issue will be resolved only or it will suspend the procedures and refer the participants to the initiation of a lawsuit or another procedure (Galič in Rijavec, Galič, 2020, p. 64). However, if in non-contentious inheritance cases there are disputable facts between the parties (e.g. validity or content of a will), on which their right depends, the court must suspend the probate hearing and refer the parties to litigation or administrative procedure (Article 210 of Inheritance Act).

\section{New regulation of the procedure for placing an adult under custody}

\subsection{Reasons for change}

The legal capacity deprivation regulation, regardless of the reason, means a serious encroachment on human rights: it completely or at least partially prevents an individual from independently deciding on their rights and benefits, forming their own will and acting independently in legal transactions.

Slovenian law denies legal capacity to adults who, due to a mental development disorder or mental health problems or other cause affecting the ability to make a judgement, are unable to take care of their rights and benefits without harming 
themselves (Article 262 FC). Due to the actual reasons, an individual may be limited in his/her ability to make independent decisions and to exercise and protect his/her rights and interests.

According to the previous regulation, in the Slovenian system two procedures were conducted in which an adult has not had legal capacity, the procedure for deprivation of legal capacity and the procedure for extension of parental rights. FC compensated the deprivation of legal capacity and extension of parental rights with the institute of placing an adult under custody, and also transferred the decision on the nomination or appointment of a custodian from the Social Work Centre to the court, which was followed by the regulation in NCCPA-1. The weaknesses of the previous regulation were pointed out both by the theory (Novak, 2003; Kraljić, 2019, pp. 1048, 1050; Novak, in: Čujovič et al., 2019, p. 830) and by the case law ${ }^{12}$, which regarding the double-track system of decision-making in the judiciary and in administrative procedures emphasized that deciding on the personal status of an incompetent person and on the scope of placement and on the person of custodian should be combined into one procedure whereby jurisdiction in non-contentious procedures would the most appropriate (Rijavec, 2001, p. 47). Under the previous regulation, two procedures were provided for the deprivation of legal capacity, and on the unified institute of custody the discretion was divided between the court and the Social Work Centres. First, the fulfilment of the conditions and the need for a custodian was established by the court, and only then did the Social Work Centre appoint a custodian with a provision (Rijavec, 2017, p. 1281). The new FC has introduced two innovations in the field of custody. The first is the abolition of the procedure for deprivation of legal capacity and the procedure of extension of parental rights and the regulation of placement under custody, and the second is the regulation of a uniform system of the district court jurisdiction in non-contentious proceed procedures both on placement under custody and on the appointment of a custodian.

Under Article 44 of the old NCCPA, in a deprivation of legal capacity procedure, the court ruled on the partial or total deprivation of legal capacity of persons who are incapable due to mental illness, mental retardation, alcohol or drug addiction or any other cause affecting the psychophysical condition to take care of themselves, their rights and benefits. Article 50 of the NCCPA provided that if the conditions for deprivation of legal capacity were met, the court would deprive persons of their legal capacity in part or in full, depending on the degree

\footnotetext{
${ }^{12}$ Regarding the preliminary regulation, the Supreme Court emphasized that the legal regulation is unacceptable from the point of view of human rights protection and the importance of the decision represented by the decision on deprivation of legal capacity and the legal regulation according to which the court decides on the partial deprivation of legal capacity, and the Social Work Centre may then, if necessary, "mitigate" such a decision by defining the scope of transactions or the area in which a person with limited legal capacity can make decisions independently.
} 
of incapacity found. The NCPPA did not specify the reasons for deprivation of legal capacity. In addition to the examples listed above, the case law also cites physical and character defects as reasons for deprivation or restriction of legal capacity.. These circumstances can be a reason for deprivation or restriction of legal capacity only when they affect the human psychophysical condition so much that he is permanently unable to take care of himself, his rights and benefits without harm to himself (Decision of the Supreme Court of the Republic of Slovenia (VS RS) II Ips 84/2019 of 03/10/2019).

The institution of custody is regulated as a way of caring for an adult in those areas of his life or in those matters where he really needs it, thus enabling persons to maintain a degree of autonomy in everyday and legal life (Kraljić, 2019, p. 1049).

\subsection{Regulation in the Family Code}

The purpose of custody for adults is to protect their personality, which is realized primarily by regulating matters that these persons cannot do on their own, and by striving for treatment and training for independent living (Article 239 (2) of FC). The court appoints a custodian to such a person, and sends the final decision on placement under custody and appointment of a custodian to the Social Work Centre (Article 262 (1) and (3) of FC), which supervises the custodian, especially on the basis of a review of the custodian's reports (Articles 250 and 251 of FC). The court thus defines the areas of life and activity in which the individual can function freely, or areas of life and activity in which he can no longer act independently, and areas in which he needs the consent of the custodian.. The court must be informed by the administrative and other state bodies, holders of public authority etc., and by the spouse, extramarital partner, relatives, household members and other persons who learn about such a case that the person must be placed under custody (Article 275 of FC).

The role of the custodian is primarily to represent the protégé, and he must diligently take care of the personality, rights and benefits of the protégé and carefully manage his property (Article 245 of FC). The custodian is independent in his work, but he must consult with the protégé before each important task and take his opinion into account if the client is able to understand what he is deciding on, and in some cases even obtain permission from the Social Work Centre for decisions such as sale of the protégé's property (Kraljić, 2018, pp. 944-94). With regard to the custody regulation, the FC provides that, if possible, the person shall be placed under custody by his or her spouse, extramarital partner or relative. A legal entity may also be appointed as a custodian, authorizing his/her employee to be the person responsible for the implementation of the custody. When choosing a custodian, the decisionmaking body must take into account the wishes of the protégé if he is able to understand the meaning and consequences, as well as the wishes of the spouse, 
extramarital partner or relatives (Article 243 of FC). The National Assembly stipulates that the Social Work Centre or the court may decide to appoint a Social Work Centre as the custodian who then authorizes an employee to perform custody. The court sends the decision on placement under custody to the administrative unit for entry in the registry and to the competent court, so that the custody is recorded on the real estate in the land register. Custody of a person placed under custody shall be terminated by a court decision if the reasons for custody have ceased.

\subsection{Procedural reforms}

The Act determines the persons who have the procedural legitimacy to file a proposal for the commencement of procedures for the placement of an adult under custody. The applicant may be a Social Work Centre, a public prosecutor, a spouse or a person living with a person to be placed under custody in a longterm community of life, or a relative in a straight line and in a side line up to the second generation. The procedural capacity for independent filing of a proposal is also recognized by law to the person to whom the procedure relates if he is able to understand the meaning and legal consequences of his proposal. If the court finds that the person on whose proposal the procedures were initiated is unable to understand the consequences of the proposal, it may initiate the procedures ex officio, provided that the conditions are met, and the person's proposal is dismissed. However, the procedure for placing an adult under custody can also be initiated ex officio. The court commences procedural acts in the procedures if it learns of the circumstances which give rise to a valid reason for placing the person under custody (Article 57 NCCPA-1).

Anyone who thinks that his legal interest may be affected by a court decision may, anytime during th entire procedure, at the hearing or by a written application, register his participation in the performance of procedural acts for which he demonstrates a legal interest. Persons closely associated with the opposing party should be allowed to take part in the procedure, regardless of whether they themselves filed a proposal to initiate the procedure. According to the case law (Decision VSL II Cp 2241/2019 of 15/07/2020), a relative who is entitled to file a proposal to place a person under custody, has the proposition right, and wishes to participate in the procedure as a participant should be allowed to participate in the procedure of placement under custody. This person's interest to participate is mainly reflected in the protection of the interests of the person who is to be decided on in the procedure of his relative and in respect of whom the relative could be appointed as a custodian.

Payment of the court fee upon filing a proposal to initiate the procedure is not a presumption of the procedure (Article 44 of NCCPA-1). Before deciding on a proposal, the court must give participants the opportunity to make statements about the allegations in the proposal, or to hold a hearing when participants can 
fully and definitively exercise their right to a statement, participation in taking of evidence and a call for results of the procedure before the court of first instance. The general duty exemption provides for the statement provided for in procedures relating to personal status in the family relationship (Article 5 (2) of NCCPA-1). In these procedures, the court will weigh the constitutional right to a statement, taking into account other rights of participants whose rights it is obliged to protect in the procedures, especially those persons whose rights the court must protect ex officio. These are persons who, due to a mental disability or mental health problem or other circumstances, are unable to take care of their own rights and interests (Article 6 (2) of NCCPA-1). The court may decide without giving the participant the opportunity to state his opinion if so provided by law or if he deems that this would endanger other constitutional rights of the person under special protection. When the court decides on the custody procedure, the rules on procedural capacity have a different meaning than in the contentious procedure (Wedam Lukić, Polajnar Pavčnik, 1991, p. 50).

A participant who is an adult placed under custody is allowed by the court, in order to assert his rights or legal interests that he himself performs individual procedural acts if he deems that he is able to understand the meaning and legal consequences of such acts. The court must respect the principle of compulsory hearings (Article 61 of NCCPA-1) in procedures placing a person under custody. In accordance with this principle, the court hears the person to be placed under custody, unless - after attempting to hear the person or obtaining his statement - it finds that the hearing would be detrimental to his health or that, depending on his state of health, the hearing is not possible. It follows from the ECHR decisions that the presence of a person at a hearing is necessary for two reasons: to allow the person to present his arguments, and to allow the judge to form a personal opinion on the person's mental capacity. A court-appointed expert shall, when necessary, assess whether the hearing is appropriate and whether the person understands the content and consequences of acts in court procedures.

\subsubsection{New regime on coercive measures}

According to Slovenian CPA, whoever is summoned as a witness has a duty to comply with the court summons, and must testify, unless otherwise stipulated by the law (Art. 229 CPA). If the witness does not respond to the court order for participating in the evidence taking procedure, the court is authorised to use coercive measure to assure that the witness will appear at the main hearing. However, there can be no coercive measures used to procure the parties' presence or testimony but there will be other procedural sanctions for the parties' absence or passivity (for example, a party who has not attended a preparatory hearing must reimburse the other party all the costs of that hearing). 
In non-contentious procedures the regulation under the old NCCPA did not provide a legal basis to the court for the use of coercive means if the opposing party was summoned to a hearing, but the latter did not respond to the summons (Decision VSL I Cp 2540/2017 of 07/03/2018); it was also not possible to force the participant to testify. In accordance with the subsidiary application of the CPA provisions in cases that the NCCPA does not regulate a certain procedural question, the court in these cases considered, in all circumstances, the significance of the fact that the participant did not come to the hearing or did not want to testify (Article 262 of CPA in connection with Article 37 of NCCPA) ${ }^{13}$. The court likewise could not order a compulsory examination by an expert regarding such a participant's health condition (Decision of the Supreme Court of the Republic of Slovenia II Ips 11/2015 of 05/03/2015).

The NCCPA only stipulated that such a person could stay temporarily, but for a maximum of seven days, in a psychiatric health organization if, in the opinion of the physicians, this was necessary to establish his medical condition (Article 49 (1) of NCCPA). This provision regulated only detention, and not forced (for example police) apprehension, and only when it was absolutely necessary in the opinion of doctors. However, the courts may appoint a temporary custodian to protect the rights and interests of the individual.

The new regulation in the NCCPA-1 binds the possibility of applying a coercive measure by apprehension to the condition that a person who was duly summoned and warned in the summons of the consequences of an unjustified absence did not attend the hearing for unjustified reasons. The apprehension is carried out by the police. In ex officio procedures, the authorizations of investigation are further emphasized, as the court also establishes facts that were not stated by the participants and also presents evidence that was not proposed by the participants (Article 7 of NCCPA-1). The court determines the conditions for placement under custody with the help of a medical expert. An examination of a person by an expert can only be omitted:

- if the person to be examined is already in a psychiatric hospital following a court decision and the hospital treatment report shows the need to place him under custody, or

- if the court already has an appropriate opinion of a medical expert, which may not be older than six months (Article 62 (3) of NCCPA-1). If the person does not come to the expert and has no excuse for the absence, the court orders that he should be brought to the expert. The apprehension shall be carried out by paramedics by ambulance, if necessary with the assistance of the police (Article 62 (2) of NCCPA-1).

\footnotetext{
${ }^{13}$ If a party fails to prove evidence without good reason, the court shall shift the burden of proof to the party in respect of which there are circumstances indicating the likelihood of his legal incapacity.
} 
The scope of the expert's work and the legally relevant facts to be explained by the expert shall be determined by the judge in the decision on the appointment of the expert. If he has to make a report in addition to the opinion, he establishes certain facts by himself (Rijavec, 2012, pp. 1394-1406).

Before the expert prepares the expert opinion, he establishes the fact, which means that he actually takes the evidence by inspecting or examining the person and documents or the available medical documentation. Based on the report on factual ground, the expert gives an opinion. In custody procedures, an important part of an expert opinion is his report: by examining the opposing party, the expert establishes facts (which require his expertise) and reports them to the court and (among other evidence) leans an expert opinion on them, which in practice is usually given first in writing and then orally at the hearing. The expert is asked to examine carefully the matter in question, to state accurately everything they notice and discover, and to produce an opinion conscientiously and pursuant to the rules of science and art. The expert in practice produces written opinions, so already in the decree of appointing the expert the court usually determines the task. The result is grouped into findings (which are the result of careful examination of the subject matter) and final expert opinion. Oral hearings with expert witnesses are held only when the court evaluates that the hearing is necessary or when the parties demand such a hearing. The judge has the duty to give questions to the expert (included already in the decree) needed to be examined by the expert witness which are as precise as possible.

According to Slovenian CPA the court decides whether the expert is to offer the opinion orally at the hearing or in writing prior to the hearing. (Art. 253 CPA.) The CPA regards the written opinion as an alternative, in practice, however, experts offer written opinions in most cases. Whenever possible, the court shall serve on the parties the expert opinion in writing before the hearing in which such opinion is to be produced. The parties have the right to give remarks on the opinion, to demand further explanations, and to propose that the expert witness should be orally examined.

It follows from the established practice of the Constitutional Court of Slovenia that an oral hearing of a court expert who has prepared a written expert opinion in court procedures means a constitutional requirement, as a rule, when the evidence by the expert is crucial for the decision in the case, and the party submitted concretized comments to the written expert opinion, which require additional explanations (Decision US RS Up-1178/18 of 12/12/2019).

As an expert opinion is crucial in custody procedures, the person against whom the procedures are pending must, as a general rule, be given the opportunity to oppose the expert opinion. The hearing of an expert is also important so that the court can remove any doubts about the correctness of the expert opinion, and may also hear the expert ex officio in accordance with the investigative powers of the expert. The Supreme Court of Slovenia (Decision of the Supreme Court of the Republic of Slovenia II Ips 267/2017 of 12/10/2017) emphasized 
New regulation of non-contentious procedures with an emphasis on...

that the adversarial principle was not violated, if the expert examined the opposing participant without the representative of the opposing participant or his custodian was not invited to be personally present at the expert examination. The right to make a statement should be provided differently in such ca,ses for example by requiring the expert to clarify the findings in detail based on the examination, and the expert then being heard at the hearing in the presence of a temporary custodian, if appointed to a person, and his representative who have an option to ask questions. The provisions of the CPA (Article 42 of NCCPA-1) (Rijavec, 2019, p. 7) shall apply mutatis mutandis to those questions concerning experts, which are not specifically regulated by NCCPA-1.

If in the opinion of the expert, it is absolutely necessary for the person to be examined in a psychiatric hospital to establish the state of health, and this takes some time, the court may order that the person be kept in a psychiatric hospital for a maximum of two days (Article 63 (1) of NCCPA-1) which is shorter than the seven days previously allowed. The basis for imposing a detention measure has also been changed. The court may order the measure on the basis of an expert opinion. When the participant does not willingly attend the examination by the expert, the old NCCPA, generally held that the relevant opinion of physicians was on the basis of which a court could order detention in psychiatric hospital for the expert to establish the state of health of the participant. A detention measure is a measure to ensure the taking of expert evidence, without which the court would not be able to determine the state of health of the person in the procedure. If the person does not come to the psychiatric hospital on a certain day and does not excuse the absence, the director of the psychiatric hospital informs the court that issued the decision and orders transport of the person by ambulance. The director of a psychiatric hospital may request the assistance of the police in carrying out emergency transport. In a decision ordering detention in a psychiatric hospital, the court must instruct the person that coercive measures will be applied in the event of an unjustified absence from the examination. However, the court will only issue a decision to examine a person in a psychiatric hospital if it receives the opinion of an expert that this is strictly necessary to establish the state of health. An appeal against such a decision may be lodged within three days and must also be decided by a court of second instance within three days (Article 63 (4) of NCCPA-1). In the event that the court orders detention, the legislature has also provided for a safeguard in the institute of appointing a temporary custodian. Thus, a temporary custodian is appointed if necessary, depending on the specific circumstances, and not automatically in every procedure, whereby the court also determines in the decision the scope of obligations and rights of the temporary custodian. The court must immediately send a final decision on placement under temporary custody and appointment of a temporary custodian to the Social Work Centre (Article 265 of FC). The temporary custodian protects the procedural rights and benefits of the person in respect of whom the procedures are pending until a final court decision. A proposer and a person employed by the proposer and 
another person whose interests are in conflict with the interests of the person to be placed under custody may not be appointed as a temporary custodian.

It is a duty of the temporary custodian to explain in an appropriate manner to the person to be placed under custody the purpose and course of the procedure, his rights and duties, as well as the consequences of unjustified non-cooperation with an expert during a psychiatric hospital examination. The temporary custodian participates independently in the procedure, which means that he can oppose this measure. The court may order the coercive apprehension of a person by ambulance and even accompanied by the police only if the person is assigned a temporary custodian who can appeal against the decision by which the court orders the person to remain in a psychiatric hospital for a maximum of two days.

A novelty that enables the court to carry out the principle of promptness is the possibility for the court to hear a person where he resides if he is unable to attend a hearing due to a medical condition (Article 61 of NCCPA-1). In this particular case, the Supreme Court (VS RS IR 121/2019 of 19/09/2019) approved the delegation of jurisdiction on the grounds of expediency, arguing that the procedure of hearing and examination by a medical expert would be easier, faster and at lower cost before the court in the place where the person being heard currently resides.

Another novelty is the authorization to the court to use a written expert opinion drawn up from another court procedure if it considers that only in this way can the benefits of persons who are unable to take care of their rights themselves be protected in a timely manner (Article 48 (2) NCCPA-1). The court will be able to use such evidence from another procedure without the proposal of the participants, the non-contentious court only to ensure the protection of specific categories of persons.

Furthermore, in the procedure for placing an adult under custody, the court may exceptionally waive the examination of a person by an expert if it already has the relevant opinion of a medical expert, but that opinion may not be older than six months (Article 62 (3) of NCCPA-1).

\section{Concluding thoughts}

Legal systems based on the heritage of Roman law are mostly distinguished between contentious (iurisdictio contentiosa) and non-contentious procedures (iurisdictio voluntaria) (Klicka, Oberhammer and Domej, 2006, p. 3). The main differences between them relate to adaptations of general procedural principles to the specific nature of a particular relationship or certain rights. The noncontentious procedure is somewhat less formal and the first procedural act is not a lawsuit but a proposal without a strict claim. A decision is not a judgment, but a decision that becomes final. Development does not go everywhere in the 
New regulation of non-contentious procedures with an emphasis on...

direction of maintaining these two types of a civil procedure, as there is also a strong influence of Anglo-American law in civil procedural law, which does not recognize such an axiomatic division.

The analysis of comparative law examples shows that family matters need to be resolved as comprehensively and uniformly as possible, which is also made possible by more flexible and less formal rules of non-contentious procedure. A harmonized procedural system needs to be created through a positive demarcation between contentious and non-contentious procedures. In determining the type of procedure, it is reasonable to pay attention that substantively similar matters are not decided in different procedures without good reason (Galič, 2000, p. 6) and that the general principles of the procedure reflect the spirit of the legal matter being regulated and thus play a role of basic procedural standards for specific non-contentious procedures.

NCCPA-1 introduced long-awaited innovations into the non-contentious law of the Republic of Slovenia. This completes the reform of the jurisdiction transfer from Social Work Centre to family courts and provides for the same type of procedure for comprehensive decision-making in family matters.

With the new regulation of the approach of placing an adult under custody, the legislature followed comparative examples and eliminated the double track procedures for deprivation of legal capacity. The institute of placement under custody will enable the adult care in those areas of his/her life or in those matters where he/she really needs it, and thus enable persons to maintain a degree of autonomy in everyday and legal life. Thus, the new regulation allows for the diversity of the extent of inability to make independent decisions, in which an individual cannot make independent and reasonable decisions. The court authorizes the transfer of decision-making to court procedures to concretely define the transactions or areas in which such a person may independently perform acts and those in respect of which he needs the permission of the custodian.

However, the system of custody, which is voluntary and honourable in Slovenia, still remains an unresolved problem. There is also no list of persons from which the court would appoint a custodian, which means that in cases where a person has no relatives or the relative does not want to take over these functions, the court appoints a Social Work Centre or a legal entity as a custodian, which in these cases is in a dual role, as a custodian and the body supervising the custodian. The institution of a custodian should be systematically regulated in a special Act that would ensure the professionalism of persons and regulate compensation for the custody services provision. 


\section{Bibliography}

Argounov, V. V. (2017). Voluntary (Non-contentious) Jurisdiction Around the World. Moscow: Gorodec.

Galič, A. (2000). Pravica do sodnega varstva v nepravdnih postopkih [The right to judicial protection in non-contentious proceedures]. Maribor: ICPMZP, Univerza v Mariboru, Pravna fakulteta.

Galič, A. (2017): Zakon o pravdnem postopku (ZPP) z uvodnimi pojasnili $k$ spremembam zakona in stvarnim kazalom [Civil Procedure Act introductionary remarks], 6. dopolnjena izdaja, Ljubljana: Uradni list Republike Slovenije Ljubljana.

Habscheid, W. J. (1971). Freiwillige Gerichtsbarkeit [Volountary Jurisdiction ]München: C. H. Beck.

Klicka, T., Oberhammer, P., Domej, T. (2006). Außerstreitverfahren [Noncontentious Proceedings]. 4. izdaja. Wien: Manz.

Kraljić, S. (2019): Družinski zakonik s komentarjem [Family Code Commentary], Maribor: Poslovna založba MB.

Kraljić, S. (2020): New Family Code and Dejudicialization of Divorce in Slovenia. Vol. 15 (2020): Balkan Social Science Review p. 157-177.

Maganić, Aleksandra (2015). Novi pravci reforme izvanparničnog prava $u$ Republici Hrvatskoj [New Directions of the reform of non-contentious law in Republic of Croatia]. Zbornik Aktualnosti građanskog procesnog prava - nacionalna i usporedna pravnoteorijska i praktična dostignuća. Split: Sveučilište u Splitu, Pravni fakultet, str. 147-172.

Misztal-Konecka, Joanna (2018). The non-litigious proceedings in Polish law and Roman iurisdictio voluntaria. V: Z. Benincasa, J. Urbanik (ur.), Mater Familias: Scriti Romanistici per Maria Zablocka, Journal of Juristic Papyrology, str. 572-573.

Novak, B. (2003): Civilnopravni položaj osebe z omejeno sposobnostjo za samostojno odločanje [Position according to civil law of a person with limited ability to make independent decisions]. Pravnik, št. 9-12, str. 579-592.

Novak, B. in Čujovič, M., in drugi (2019): Komentar Družinskega zakonika [Commentary of the Family Code]. Ljubljana: Uradni list Republike Slovenije.

Rechberger, W. H. (2013). Außerstreitgesetz [Non-contesting proceedings Act] Kommentar. Wien: Verlag Österreich.

Rijavec, V. (2001): Odločanje o poslovni sposobnosti v nepravdnih postopkih [Decision-making on legal capacity in non-contentious proceedings]. v: Rijavec, V. (ur.), in drugi, Nepravdno pravo, zbornik referatov, Maribor: Pravna fakulteta, str. 71-79.

Rijavec, V. (2012): Dokaz z izvedenci [Court appointed expert as evidence]. Podjetje in delo, št. 6-7, str. 1394-1406.

Rijavec, V. (2017): Postopki v družinskih zadevah po sprejemu Družinskega zakonika [Procedures in family matters after the adoption of the Family Code]. Podjetje in delo, št. 6-7, str. 1279-1301. 
New regulation of non-contentious procedures with an emphasis on...

Rijavec, V. (2019): Odločanje o varstvu in vzgoji otrok [Decisions on protection and raising of children]. Pravni letopis, str. 57-77, 282-283.

Rijavec, V. in Ude, L., and others (2009): Pravdni postopek: zakon s komentarjem [Civil Procedure - Commentary]. knjiga 3, Ljubljana: Uradni list Republike Slovenije; GV Založba.

Rijavec, V., Galič, A., (2020). Zakon o nepravdnem postopku (ZNP-1): Razširjena uvodna pojasnila [Non-Contentious Civil Procedure Act (NCCPA-1): Extended introductory explanations]. Ljubljana, Lexpera, GV Založba.

Rijavec, V., Ivanc, T. (2018): Primerjalnopravni pregled nepravdnih postopkov $v$ družinskih zadevah $v$ razvojni perspektivi [Comparative legal review of non-contentious civil proceedings in family matters in a development perspective]. Podjetje in delo, št. 6-7, str. 1265-1280.

Rosenberg, L., Schwab, K. H., Gottwald, P. (2010). Zivilprozessrecht [Civil procedural law]. München: C. H. Beck.

Silvestri, E. (2014), in: Uzelac, Alan (2014). Goals of Civil Justice and Civil Procedure in Contemporary Judicial Systems. Ius Gentium: Comparative Perspectives on Law and Justice, vol. 34. Cham: Springer.

Triva, S., Dika, M. (2004). Građansko parnično procesno pravo [Civil Procedure Law - Commentary], Zagreb: Narodne novine.

Wedam Lukić, D., Polajnar Pavčnik, A. (1991): Nepravdni postopek: zakon s komentarjem [Non-contentious proceedure - Commentary] Ljubljana: Uradni list Republike Slovenije.

\section{Legislation}

Austrian Contentious Procedures Act [Zivilprozessordnung - ZPO] : RGB1. No. $113 / 1895$ of 01/08/1895, https://www.ris.bka.gv.at/GeltendeFassung.wxe?Abfrage=Bundesnor men\&Gesetzesnummer=10001699, Accessed October 2021.

Austrian Non-Contentious Civil Procedure Act [Außerstreitgesetz - AußStrG]: Bundesgesetz über das gerichtliche Verfahren in Rechtsangelegenheiten außer Streitsachen (BGB1. I, No. 111/03, last amendment BGBl. I, No. 58/18), https://www.ris.bka.gv.at/GeltendeFassung.wxe?Abfrage=Bundesnor men\&Gesetzesnummer=20003047, Accessed October 2021

Civil Procedures Act [Zivilprozessordnung - ZPO]: RGB1. S. 83 of 30/01/1877, https://www.ris.bka.gv.at/GeltendeFassung.wxe?Abfrage=Bundesnor men\&Gesetzesnummer=10001699, Accessed October 2021.

Družinski zakonik [Family code]: Uradni list RS, 15/17, 21/18; 67/19-ZMatRC, http://www.pisrs.si/Pis.web/pregledPredpisa?id=ZAKO7556.

Family and Non-Contentious Civil Procedure Act [Gesetz über das Verfahren in Familiensachen und in den Angelegenheiten der freiwilligen Gerichtsbarkeit - FamFG]: BGB1. I S. 2586, 2587 of 17/12/2008 and 
last amendment Art. 7 G v. (BGB1. I S. 2780 of 20/07/2017), https://www.gesetze-im-internet.de/famfg/, Accessed October 2021.

Federal Law on Non-contentious Procedure [Gesetz über die Angelegenheiten der freiwilligen Gerichtsbarkeit - FGG]: RGBl. S. 189 of 17/05/1898, https://www.gesetze-im-internet.de/famfg/.

German Non-Contentious Civil Procedure Act [Gesetz über die Angelegenheiten der freiwlligen Gerichtsbarkeit - FGG]: RGB1. S. 369, 771 of 20/05/1898, https://www.gesetze-im-internet.de/famfg/, Accessed October 2021.

Gesetz zur Reform des Verfahrens in Familiensachen und in den Angelegenheiten der freiwilligen Gerichtsbarkeit (FGG-Reformgesetz - FGG-RG), BGB1. I S. 2586, https://www.gesetze-im-internet.de/fggrg/BJNR258600008.html, Accessed October 2021.

Italian Code of Civil Procedure [Codice di procedura civile - Gazzetta Ufficiale del Regno d'Italia n. 253 of 28/10/1940], https://www.studiocataldi.it/codiceproceduracivile/codicediprocedura civile.pdf, Accessed October 2021.

Zakon o nepravdnem posotpku: ZNP [Non-Contentious Civil Procedure Act (NCCPA)]: Uradni list SRS, št. 30/86, 20/88 - popr., Uradni list RS, št. 87/02 - SPZ, 131/03 - odl. US, 77/08 - ZDZdr, 10/17 - ZPP-E in 16/19 - $\quad$ ZNP-1), http://www.pisrs.si/Pis.web/pregledPredpisa?id=ZAKO492, Accessed 2021.

Zakon o nepravdnem postopku: ZNP-1 [Non-Contentious Civil Procedure Act: NCCPA-1]: Uradni list $\quad$ RS, 16/19, http://www.pisrs.si/Pis.web/pregledPredpisa?id=ZAKO7879, Accessed October 2021.

Zakon o pravdnem postopku [Civil Procedure Act: CPA]: Uradni list RS, št. 73/07 - uradno prečiščeno besedilo, 45/08 - ZArbit, 45/08, 111/08 odl. US, 57/09 - odl. US, 12/10 - odl. US, 50/10 - odl. US, 107/10 odl. US, 75/12 - odl. US, 40/13 - odl. US, 92/13 - odl. US, 10/14 odl. US, 48/15 - odl. US, 6/17 - odl. US, 10/17, 16/19 - ZNP-1 in 70/19 - odl. http://pisrs.si/Pis.web/pregledPredpisa?id=ZAKO1212, Accessed 2021.

\section{Case Law}

Constitutional Court of the Republic of Slovenia, Decision UI-273/98 of 1 July 1999.

Constitutional Court of the Republic of Slovenia, Decision US RS Up-1178/18 of $12 / 12 / 2019$.

ECLI:SI:VSRS:2019:II.IPS.84.2019: Decision of the Supreme Court of the Republic of Slovenia (VSRS Sklep II Ips 84/2019 of 03/10/2019).

ECLI:SI:VSRS:2019:I.R.121.2019: Decision of the Supreme Court of the Republic of Slovenia (VS RS sklep IR 121/2019 of 19/09/2019). 
ECLI:SI:VSRS:2019:II.IPS.267.2018: Decision of the Supreme Court of the Republic of Slovenia (VSRS Sodba II Ips 267/2017 of 12/10/2017).

ECLI:SI:VSRS:2015:II.IPS.11.2015: Decision of the Supreme Court of the Republic of Slovenia (VSRS Sklep II Ips 11/2015 of 05/03/2015).

ECLI:SI:VSLJ:2020:II.CP.2241.2019: Decision of the High Court of Ljubljana (VSL II Cp 2241/2019 of 15/07/2020).

ECLI:SI:VSLJ:2018:I.CP.2540.2017: Decision of the High Court of Ljubljana (VSL I Cp 2540/2017 of 07/03/2018). 
